\title{
EIF2B4 wt Allele
}

National Cancer Institute

\section{Source}

National Cancer Institute. EIF2B4 wt Allele. NCI Thesaurus. Code C53136.

Human EIF2B4 wild-type allele is located in the vicinity of 12 p23.3 and is approximately 6 $\mathrm{kb}$ in length. This allele, which encodes translation initiation factor elF-2B subunit delta protein, is involved in the progression of translation. Mutations in the gene are linked to both leukoencephalopathy with vanishing white matter and ovarioleukodystrophy. 